The Egyptian Journal of Biochemistry \& Molecular Biology VOL 37(N.1\&2) 61-74 December. 2019

\title{
MIR 129 5-P AS A NONINVASIVE PROGNOSTIC BIOMARKER OF LIVER FIBROSIS IN HCV EGYPTIAN POPULATION
}

Shymaa E. Ayoub1, Olfat G. Shaker 2, S, Essam A. Hassan3, Tarek I.Ahmed4, Naglaa A. Ahmed5, Mostafa Y. Abdelwahed 6

Department of Medical Biochemistry and Molecular Biology

Received 24/3/2019 - Accepted 17/4/2019

\begin{abstract}
MiR 129 5-p as a noninvasive prognostic biomarker of liver fibrosis in HCV Egyptian population

Background: Hepatic fibrosis is the inevitable pathological process of chronic hepatitis $\mathrm{C}$ (CHC), Accurate assessment of liver fibrosis has an important role in determining prognosis and to follow-up disease progression. Current aim was to evaluate MiR 129 5-p as a noninvasive serum marker for assessment of liver fibrosis in chronic hepatitis C Egyptian populations. Subject and Methods: Eighty HCV patients complicated by liver fibrosis and 80 subjects were enrolled as controls. MiRNA expression level was tested using miScript SYBR Green PCR Kit (Qiagen, USA). Results : Results showed significant differences between the HCV patients and controls as regard the mean \pm SD of expression level of MiR-129-5p with down- regulation in HCV patients $(0.10 \pm 0.02)(\mathrm{P}<0.0001)$. The results also showed that $\mathrm{MiR} 129-5 \mathrm{p}$ relative expression level was significantly down-regulated in sever fibrosis (F3-F4) compared with mild fibrosis (F1-F2). ROC curve analysis showed the prognostic value of MiR 129-5p to differentiate between severe fibrosis (F3 and F4) from mild (F1, F2) (sensitivity $=70 \%$ and specificity $=90 \%$ ).
\end{abstract}

Conclusion: miR-129- $5 \mathrm{p}$ might be a potential prognostic biomarker for liver fibrosis.

Keywords: Liver fibrosis, CHC, MiR129-5p.

* Correspondence Author (Shymaa E. Ayou6) 


\section{INTRODUCTION}

Chronic hepatitis $\mathrm{C}$ (CHC) constitutes a major public health problem, affecting around 200 million people worldwide (Lavanchy, 2009). Egypt has a high HCV prevalence in the world (Houldsworth, 2017) .CHC could be complicated by fibrosis, cirrhosis, and hepatocellular carcinoma (Bostan and Mahmood, 2010).

Hepatic stellate cells play the most important role in liver fibrosis pathogenesis (Xiaoying et al., 2010 , Teng and Ghoshal, 2015) Upon its activation by various causes of hepatic fibrosis it is transformed to myofibroblasts which interact with hepatic epithelial cells and pro-inflammatory immune cells ending in hepatic fibrosis (Pellicoro et al., 2014).

Accurate assessment of liver fibrosis has an important role in prognosis and to follow-up disease progression, Liver biopsy remains the most accurate diagnostic tool for assessing liver fibrosis despite it has some limitations like invasiveness, sampling error, and variability in pathological interpretation. (Bravo et al., 2001 , Bedossa et al., 2003 , Friedman 2004).

Many studies reported the role of microRNA in various liver diseases as liver fibrosis and hepatocellular carcinoma (Wang et al., 2012, Szabo and Bala 2013). MiRNA-15a promoting metastasis of cholangiocarcinoma cells (Utaijaratrasmi et al., 2018). MiR-122 act as biomarker in drug-induced liver fibrosis (Howell et al., 2018) miR34 family induce hepatic fibrosis in rats (Li et al., 2011).

MiR 129-5-p has been investigated in hepatocellular carcinoma Luo et al (2017) demonstrated that MiR-129-5p through downregulation of VCP/P97 (Valosin containing protein) could regulate the progression of hepatocellular carcinoma. A study by Li et al (2015) reported the role of MiR-129-5p in renal fibrosis through suppressing of its target gene 3 Phosphoinositide Dependent Protein Kinase 1 (PDPK1) suggesting that Mir 129-5-p may acts as a suppressor in renal fibrosis. The aim of this study was to evaluate MiR 129 5-p as a noninvasive serum marker for assessment of liver fibrosis in chronic hepatitis $\mathrm{C}$ Egyptian populations 


\section{MATERIALS AND METHODS}

\section{Subjects}

Our study included 160 subjects divided into 80 as healthy subjects considered as control (50male and 30 female) and 80 patients (56 male and 24 female) with HCV. They had various degrees of fibrosis with no previous antiviral therapy. Abdominal ultrasound was done to all patients. Liver biopsy from each patient was taken in Tropical and Internal Medicine departments, Fayoum University Hospital, Egypt. Exclusion criteria: vascular disorders (eg.hemangioma), Bleeding tendency. Biopsy specimens were processed using standard techniques. Patients were classified according to Metavir fibrosis scoring system (Bedossa , 1993) which is used to describe the amount of inflammation (the intensity of inflammation/breakdown of tissue) in the liver into F1: Portal fibrosis without septa,F2: Portal fibrosis with few septa ,F3: Numerous septa without cirrhosis ,F4: Cirrhosis and according to activity score (Knodell et al., 1981) which is a prediction about how rapidly the degree of fibrosis is progressing into A1: Mild activity,A2: Moderate activity,A3: Severe activity.

Patients were classified regarding liver activity into $32.5 \%$ was grad $\mathrm{A} 1$, and $47.5 \%$ was grade A2, $20 \%$ was A3 and as regards liver fibrosis degrees; $22 \%$ of them were F1, degree, $38 \%$ had F2 degree, 8 $\%$ of them had F3 degree and $12 \%$ of them had F4 degree of fibrosis. Patients were enrolled from departments of Tropical and Internal Medicine, Fayoum University Hospital, Egypt. Written informed consent was obtained from all patients. All human studies have been revised and approved by Ethics Committee at Faculty of Medicine, Fayoum University.

\section{Samples collection}

$7 \mathrm{ml}$ blood were withdrawn and collected in 3 tubes one of them contain EDTA and was stored at $-80^{\circ} \mathrm{C}$ for $\mathrm{CBC}$ and molecular biology analysis, the second contain sodium citrate for PT measurement and the $3^{\text {rd }}$ plain tube after centrifugation $2000 \mathrm{Xg}$ for 5 minutes was used for determination of all serological tests. 


\section{Routine tests}

Complete blood picture using Automatic blood cell counter ( Cell Dyne-2700,Abbott Lab ,US ), liver biochemical profile (using Biosystem kits), prothrombin time and concentration (using Human kits) Renal function tests : Urea , Creatinine (using Reactivos GPL) AFP (using Siemens Healthcare Diagnostic,USA) Serum HCV RNA levels using quantitative real-time PCR (Qiagen, Hilden, Germany) were done to all samples.

\section{RNA extraction and Reverse transcription reactions:}

RNAs were extracted from whole blood using Qiagen, Valenica, CA, USA) . RNAs were reversed transcribed into cDNAs using (Qiagen, Valenica, CA) RT-PCR kit. MiRNA 129- 5p expression level was evaluated using miScript SYBR Green PCR Kit (Qiagen, USA). The primer for microRNA-1295p was supplied by Qiagene, Germany (catalogue number MS00006643 Lot. number 117836167) . MiRNA SNORD68 was used as internal control (Cat No MS00033712). Realtime PCR was done using Rotor gene Q System (Qiagen) .After completion of the PCR cycles, melting curve analysis was performed to validate the specific generation of the expected PCR product. The relative expression of RNA was calculated by the $2-\Delta \Delta \mathrm{Ct}$ method for relative quantification (Livak and Schmittgen. 2001).

\section{Statistical analysis}

SPSS software statistical computer package version 18 (SPSS Inc, USA) was used for analyzing data. For quantitative data, the mean, standard deviation (SD) and standard error of mean (SEM) were calculated. Independent t-test or one way ANOVA was used in comparing between any two or three groups, respectively. For quantitative non parametric data kruskal wallis test used in comparing more than two independent groups, Mann-Whitney test in comparing two independent groups. Pearson correlation test to test association between variables. ROC curve was used to demonstrate MiR 129-5p as a predictor in differentiating between grades of fibrosis. Significance was adopted at $\mathrm{P} \leq 0.05$. 


\section{RESULTS}

\section{Demography and laboratory characteristics of the study groups:}

Table 1 showed that there was a highly statistically significant difference between hepatitis $\mathrm{C}$ patients when compared to control subjects as regards the mean values \pm SD of WBCx1000 AST, ALT, ALP , D.Bilirubin , serum Creatinine, PC, $(\mathrm{P}<0.0001)$ for each one, Urea , $\operatorname{AFP}(\mathrm{P}<0.011)$ for each one. (Table1).

Also there was significant differences between the HCV patients and controls as regard the mean \pm SEM of relative expression level of MiR-129-5p with down regulation in HCV patients $(0.10 \pm 0.02)$ while in control was $(0.93 \pm 0.02)(\mathrm{P}<0.0001)$ (Table 2).

Correlation of expression level of MiR-129-5p with study parameters among cases

Table (3) showed that there was positive significant correlation between the expression level of MiR-129-5p and ALT ( $p=0.016)$, ALP $(p<0.0001)$ and serum Creatinine $(p<0.0001)$ while there was negative significant correlation between the relative expression level of MiR-129-5p and $\mathrm{Hb} \%$ level $(\mathrm{p}=0.003)$, platelet count $(\mathrm{p}=0.015)$ and $\mathrm{PC}(\mathrm{p}=0.028)$.

\section{Differences in MiR 129-5p according to liver activity and fibrosis}

The results showed that there was no significant difference in MiR 129-5p expression level according to liver activity, Meanwhile there was significant difference in MiR 129-5p relative expression level according to degrees of liver fibrosis $(\mathrm{p}<0.0001)$ (Table 4)

ROC curve of Sensitivity and Specificity of MiR 129-5p as a fibrotic marker

Figure (1) illustrates the ROC curve of MiR 129-5p in chronic hepatitis patients $\mathrm{C}$ complicated with fibrosis, showing the prognostic value of MiR 129-5p to differentiate between severe fibrosis (III and IV) from mild. It was found to be significant at Cut off point $=0.035$, sensitivity $=70 \%$, specificity $=90 \%, \mathrm{PPV}=66 \%, \mathrm{NPV}=79.4 \%$ with total accuracy $=82.1 \%$. 
Shymaa E. Ayoub et all

(Table 1) Basic \& laboratory characteristics of study groups

\begin{tabular}{|c|c|c|c|c|c|c|}
\hline & \multicolumn{2}{|c|}{ Cases $(\mathbf{N}=\mathbf{8 0})$} & \multicolumn{2}{|c|}{ Control $(\mathrm{N}=\mathbf{8 0})$} & \multirow{2}{*}{$\begin{array}{c}\mathrm{t} / \mathrm{U} \\
\text { value }\end{array}$} & \multirow[b]{2}{*}{ P-value } \\
\hline & Mean & $\pm \mathrm{SD}$ & Mean & $\pm \mathrm{SD}$ & & \\
\hline Age & 42.59 & 8.48 & 40.73 & 1.4 & $\begin{array}{c}\mathrm{t}= \\
1.769\end{array}$ & $0 . \cdot 79$ \\
\hline Hb g/dl & 13.63 & 0.92 & 13.65 & 8.4 & 2868 & 0.380 \\
\hline WBCx1000 & 6.80 & 1.83 & 5.82 & 2.1 & 2072 & $<0.0001 *$ \\
\hline PLT.x1000 & 217.13 & 91.2 & 204.98 & 75.6 & 2744 & 0.120 \\
\hline AST IU/L & 51.35 & 3.53 & 28.88 & 0.71 & 1260 & $<0.0001 *$ \\
\hline ALT IU/L & 62.78 & 0.71 & 26.68 & 5.65 & 514 & $<0.0001 *$ \\
\hline ALP & 123.57 & 3.53 & 42.45 & 3.53 & 346 & $<0.0001 *$ \\
\hline T.Bil & 0.82 & 0.84 & 0.77 & 0.63 & 2894 & 0.292 \\
\hline D.Bil & 0.48 & 0.71 & 0.15 & 0.07 & 864 & $<0.0001 *$ \\
\hline $\begin{array}{l}\text { Albuming } \\
\text { g/dl }\end{array}$ & 3.96 & 0.35 & 3.83 & 0.35 & 2782 & 0.152 \\
\hline Urea & 30.20 & 0.35 & 26.03 & 0.71 & 2456 & 0.011* \\
\hline $\begin{array}{l}\text { serum } \\
\text { Creatinine }\end{array}$ & 0.91 & 0.07 & 0.70 & 0.07 & 2146 & $<0.0001 *$ \\
\hline PC & 85.80 & 0.05 & 91.70 & 0.12 & 1800 & $<0.0001 *$ \\
\hline AFP & 7.69 & 0.92 & 5.68 & 0.21 & 2458 & 0.011* \\
\hline
\end{tabular}

Abbreviations: $\mathrm{Hb}$ gl/dl , Haemoglobin ; WBC,White blood cell ; PLT.,platelet count; AST , aspartate transaminase; ALT,alanine transaminase ; ALP, Alkaline phosphatase ; T.Bil,Total bilirubin; D.Bil,Direct bilirubin ; PC.prothrombin concentration;AFP,Alfa fetoprotein.

Statistical analysis is performed by the independent $t$ test or Mann-Whitney U- test *Significant 
MiR 129 5-p as a noninvasive prognostic biomarker

(Table 2) Comparison between HCV patients \& control as regards relative expression level of MiR-129-5p

\begin{tabular}{|c|c|c|c|c|}
\hline \multirow[t]{2}{*}{ Variables } & $\begin{array}{c}\text { Patients } \\
(\mathrm{N}=80)\end{array}$ & $\begin{array}{c}\text { Control } \\
(\mathrm{N}=80)\end{array}$ & \multirow[t]{2}{*}{$\begin{array}{c}\mathrm{U}- \\
\text { value }\end{array}$} & \multirow[t]{2}{*}{ P-value } \\
\hline & \multicolumn{2}{|c|}{ mean \pm SEM } & & \\
\hline \multirow{3}{*}{$\begin{array}{l}\text { Relative expression } \\
\text { level of MiR-129-5p }\end{array}$} & $0.10 \pm 0.02$ & $0.93 \pm 0.02$ & 124 & $<0.0001^{*}$ \\
\hline & \multicolumn{2}{|c|}{ Median (range) } & & \\
\hline & $0.06(0.002-0.99)$ & $\begin{array}{c}0.98 \\
(0.57- \\
1.45)\end{array}$ & & $<0.0001^{*}$ \\
\hline
\end{tabular}

Statistical analyses were performed by the Mann-Whitney U- test *Significant

Table (3): Correlation of expression level of MiR-129-5p with study parameters among cases

\begin{tabular}{|l|c|c|}
\hline \multirow{2}{*}{ Age } & \multicolumn{2}{|c|}{ MiR 129-5p } \\
\cline { 2 - 3 } & $\mathrm{r}$ & P-value \\
\hline Hb gl/dl & 0.171 & 0.128 \\
\hline WBCx1000 & -0.328 & $0.003^{*}$ \\
\hline PLT.x1000 & -0.091 & 0.421 \\
\hline AST IU/L & -0.27 & $0.015^{*}$ \\
\hline ALT IU/L & -0.026 & 0.819 \\
\hline ALP & 0.268 & $0.016^{*}$ \\
\hline T.Bil & 0.428 & $<0.0001^{*}$ \\
\hline D.Bil & -0.004 & 0.974 \\
\hline Albumin g/dL & 0.18 & 0.111 \\
\hline Urea & 0.046 & 0.686 \\
\hline Serum Creatinine & 0.04 & 0.726 \\
\hline PC & 0.448 & $<0.0001^{*}$ \\
\hline AFP & -0.245 & $0.028^{*}$ \\
\hline HCV RNA Quant & -0.05 & 0.661 \\
\hline
\end{tabular}

Statistical analyses were performed by Spearman correlation *Significant 
Shymaa E. Ayoub et all

Table (4): Differences in MiR 129-5p according to liver activity and fibrosis degrees

\begin{tabular}{|c|c|c|c|c|}
\hline & Mean & SEM & $\chi^{2}$ value & P-value \\
\hline \multicolumn{5}{|c|}{ Liver activity } \\
\hline A1 $(\mathrm{N}=26)$ & 0.13 & 0.05 & \multirow{3}{*}{2.583} & \multirow{3}{*}{0.275} \\
\hline A2 $(\mathrm{N}=38)$ & 0.08 & 0.02 & & \\
\hline A3 $(\mathrm{N}=16)$ & 0.11 & 0.05 & & \\
\hline \multicolumn{5}{|c|}{ Liver fibrosis } \\
\hline $\mathrm{F} 1(\mathrm{~N}=22)$ & 0.20 & 0.06 & \multirow{4}{*}{20.931} & \multirow{4}{*}{$<0.0001 *$} \\
\hline $\mathrm{F} 2(\mathrm{~N}=38)$ & 0.09 & 0.02 & & \\
\hline $\mathrm{F} 3(\mathrm{~N}=8)$ & 0.04 & 0.01 & & \\
\hline $\mathrm{F} 4(\mathrm{~N}=12)$ & 0.03 & 0.01 & & \\
\hline
\end{tabular}

SEM, Standard error of mean

Statistical analyses were performed by the Kruskal Wallis H test

*Significant 
Figure (1): The Receiver Operating Characteristic (ROC) curve of Sensitivity and Specificity of MiR 129-5p between mild and sever cases

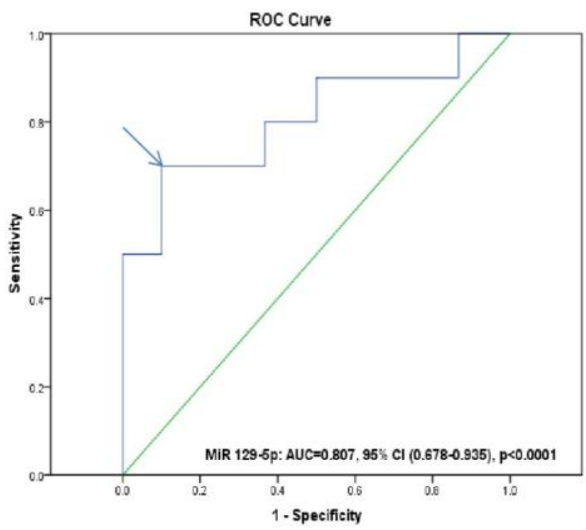

Cut off point $=0.035$, sensitivity $=70 \%$ and specificity $=90 \%, \mathrm{PPV}=66 \%$, $\mathrm{NPV}=79.4 \%$, total accuracy $=82.1 \%$. 


\section{DISCUSSION}

170 million people, representing $2.5 \%$ of the entire world population, are infected with hepatitis C virus (HCV) (Boesecke et al., 2012) .The assessment of liver fibrosis represents the key investigation for disease prognosis and management for patients with CHC (Sebastiani and Alberti 2006) .Circulating miRNAs which have a role in liver fibrosis could be used as non-invasive markers determining the degree of fibrosis (El-Ahwany et al., 2016, Matsuura K et al., 2016).

Some miRNA have been investigated to have a role in pathogenesis of the liver disease, such as cirrhosis (Hsi E et al., 2014 and Segarra et al., 2016) and viral infection (Ura et al., 2009) and could be used as biomarkers in predicting treatment response for $\mathrm{CHC}$ patients (Sarasin-Filipowicz et al. 2009).

MiRNAs have an important role in hepatic stellate cell (HSC) activation, migration, differentiation, proliferation, and apoptosis (Kitano and Bloomston 2016). In liver injury stellate cells become activated to a myofibroblaste secreting fibrillar collagens, elastin and matrix proteins (Pellicoro et al., 2012). A study by Yinghua Chen et al (2018) demonstrated that Osteopontin increase collagen I synthesis in hepatic stellate cells by miRNA-129-5p inhibition.

The results showed that there was significant differences between the $\mathrm{HCV}$ patients and controls as regard the mean \pm SEM of relative expression level of MiR-129-5p with down regulation in HCV patients $(0.10 \pm 0.05)$ while in control was $(0.93 \pm 0.01)(\mathrm{P}<0.0001)$ (Table 2). As regards Correlation of expression level of MiR-129-5p with study parameters among cases we showed that there was positive significant correlation between the relative expression level of MiR-129-5p and $\operatorname{ALT}(\mathrm{p}=0.016), \operatorname{ALP}(\mathrm{p}<0.0001)$ and serum Creatinine $(\mathrm{p}<0.0001)$ while there was negative significant correlation between relative expression level of MiR-129-5p and $\mathrm{Hb} \%$ level $(\mathrm{p}=0.003)$, platelet count $(\mathrm{p}=0.015)$ and PC $(\mathrm{p}=0.028)$ (Table 3$)$

Results showed that there was no significant difference in MiR 129-5p relative expression level according to liver activity, Meanwhile there was significant difference in MiR 129-5p relative expression level according 
to degrees of liver fibrosis $(\mathrm{p}<0.0001)$. MiR $129-5 \mathrm{p}$ relative expression level was downregulated in significant fibrosis (F3-F4) compared with mild fibrosis (F1-F2). (Table 4).

Prognostic performance analysis showed the prognostic value of MiR 129-5p to differentiate between severe fibrosis (F3 and F4) from mild $(\mathrm{F} 1, \mathrm{~F} 2)$. It was found to be significant at Cut off point $=0.035$, sensitivity $=70 \%$, specificity $=90 \%, \quad \mathrm{PPV}=66 \%, \mathrm{NPV}=79.4 \%$ with total accuracy $=82.1 \%$ (Figure 1 ). According to the obtained data we suggested that miR-129- $5 \mathrm{p}$ might be a potential prognostic biomarker for liver fibrosis

Conflict of interest No conflict of interest.

Funding Information No financial support was provided relevant to this study.

\section{REFERENCES}

Bedossa P. (1993): Présentation d'une grille d'analyse informatisée pour le recueil des lésions histopathologiques dans l'hépatite chronique virale C. Etude coopérative du groupe METAVIR. Ann Pathol. 13: 260-265 Bedossa P, Dargere D, Paradis V. (2003): Sampling variability of liver fibrosis in chronic hepatitis C. Hepatology.38:1449-57.

Boesecke C., JC. Wasmuth . HepatitisC.1. Rockstroh, Sarrazin, Wedemeyer (2012): third edition, Flying Publisher, Germany, Hepatology p.44-54.

Bostan N, Mahmood T. (2010): An overview about hepatitis C: a devastating virus. Crit Rev Microbiol. 36(2):91-133.

Bravo AA, Sheth SG, Chopra S. (2001): Liver biopsy. N Engl J Med.344:495-500.

El-Ahwany E, Nagy F, Zoheiry M, et al. (2016): Circulating miRNAs as predictor markers for activation of hepatic stellate cells and progression of $\mathrm{HCV}$-induced liver fibrosis. Electron Physician. 8:1804-1810.

Friedman LS. (2004): Controversies in liver biopsy: who, where, when, how, why? Curr Gastroenterol Rep. 6:30-6. 
Houldsworth A (2017): Exploring the possibility of arthropod transmission of HCV. J Med Virol. 89(2):187-194.

Howell LS, Ireland L, Park BK and Goldring CE (2018): MiR-122 and other microRNAs as potential circulating biomarkers of drug-induced liver injury. Expert Rev Mol Diagn 18: 47-54,

Hsi E, Huang CF, Dai CY, et al. (2014): Peripheral blood mononuclear cells microRNA predicts treatment outcome of hepatitis $\mathrm{C}$ virus genotype 1 infection. Antiviral Res.; 105:135-142.

Kitano M, Bloomston PM. (2016): Hepatic stellate cells and microRNAs in pathogenesis of liver fibrosis. J Clin Med. 5:38

Knodell RG, Ishak KG, Black WC, et al. (1981): Formulation and application of a numerical scoring system for assessing histological activity in asymptomatic chronic active hepatitis. Hepatology.1:431-5.

Lavanchy D. (2009): The global burden of hepatitis C. Liver Int. 29 Suppl 1:74-81.

Livak KJ, Schmittgen TD. (2001) : Analysis of relative gene expression data using real-time quantitative PCR and the 2(-Delta Delta $\mathrm{C}(\mathrm{T})$ ) method. Methods. 25:402-408.

Li W.Q., Chen C., Xu M.D., Guo J., Li Y.M., Xia Q.M., Liu H.M., He J., Yu H.Y., Zhu L. (2011): The rno-miR-34 family is upregulated and targets acsl1 in dimethylnitrosamine-induced hepatic fibrosis in rats. FEBS J. 278:1522-1532.

Li Y, An H, Pang J, Huang L, Li J, Liu L. (2015): MicroRNA profiling identifies miR-129- 5p as a regulator of EMT in tubular epithelial cells. Int J Clin Exp Med. 8:20610-20616

Luo Fang, Jiao Sun, Zongfu Pan, Yu Song, Like Zhong, Yiwen Zhang, Yujia Liu, Xiaowei Zheng, and Ping Huang (2017):Long noncoding RNA NEAT1 promotes hepatocellular carcinoma cell proliferation through the regulation of miR-129-5p-VCP-IkB Am $J$ Physiol Gastrointest Liver Physiol 313: G150-G156.

Matsuura K, De Giorgi V, Schechterly C, et al. (2016): Circulating let7 Levels in plasma and extracellular vesicles correlate with hepatic fibrosis progression in chronic hepatitis C. Hepatology. 64:732-745.

Pellicoro A., Aucott R.L. , Ramachandran P. , Robson A.J., et al. (2012): Elastin accumulation is regulated at the level of degradation 
MiR 129 5-p as a noninvasive prognostic biomarker

bymacrophagemetalloelastase (MMP-12) during experimental liver fibrosis, Hepatology 55 (6) 1965-1975

Pellicoro A, Ramachandran P, Iredale JP, Fallowfield JA (2014):

Liver fibrosis and repair: immune regulation of wound healing in a solid organ. Nature Reviews Immunology.14:181-194.

Sarasin-Filipowicz M, Krol J, Markiewicz I, Heim MH, Filipowicz W. (2009): Decreased levels of microRNA miR-122 in individuals with hepatitis $\mathrm{C}$ responding poorly to interferon therapy. Nat Med. 15(1):31-33.

Sebastiani G, Alberti A (2006): Noninvasive fibrosis biomarkers reduce but not substitute the need for liver biopsy. World J Gastroenterol, 12(23):3682-3694.

Segarra G, Cortina B, Mauricio MD, et al. (2016): Effects of asymmetric dimethylarginine on renal arteries in portal hypertension and cirrhosis. World J Gastroenterol.;22(48): 10545.

Szabo G and Bala S (2013): MicroRNAs in liver disease. Nat Rev Gastroenterol Hepatol 10: 542-552.

Teng KY and Ghoshal K . (2015): Role of noncoding RNAs as biomarker and therapeutic targets for liver fibrosis. Gene Expr. 16:155162

Ura S, Honda M, Yamashita T, et al. (2009):Differential microRNA expression between hepatitis $\mathrm{B}$ and hepatitis $\mathrm{C}$ leading disease progression to hepatocellular carcinoma. Hepatology. 49(4): 1098-1112.

Utaijaratrasmi P, Vaeteewoottacharn K, Tsunematsu T et al. (2018): The microRNA-15a-PAI-2 axis in cholangiocarcinoma-associated fibroblasts promotes migration of cancer cells. Mol Cancer 17: 10.

Wang XW, Heegaard NH and Orum H (2012): MicroRNAs in liver disease. Gastroenterology 142: 1431-1443.

Xiaoying Jiang, Eleni Tsitsiou, Mark A. et al. (2010): MicroRNAs and the regulation of fibrosis. FEBS J. 277:2015-21.

Yinghua Chenb,1, Yitao Oua,c,1, Jiale Donga, Guizhi Yanga, Zhi Zenga, Ying Liua, Bing Liua, Weidong Lia, Xiaoshun Heb, Tian Lana (2018): Osteopontin promotes collagen I synthesis in hepatic stellate cells by miRNA-129-5p inhibition" [Exp. Cell Res. 362(2) 343348 


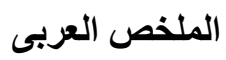

العدوى بفيروس الألتهاب الكبدى الوبائى (سى) يصيب ملايين الأشخاص فى جميع أنحاءالعالم وهو يؤدى لحدوث أمر اض الكبد المزمنة وربما يتطور الى تلبف وسرطان الكبد

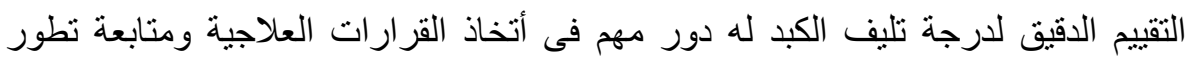

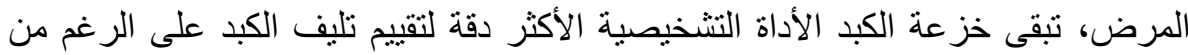
وجود بعض القيود مثل الغزو ،خطأ فى أخذ العينات ،و التباين فى نتيجة عينات الباتولوجى ـ أن الهدف من هذة الدر اسة هو قياس نسبة MiR 129-5-p كمؤشر لتقييم درجة تليف الكبد فى المرضى المصريين المصابين بألتهاب الكبد الوبائى C تجنباً للأثار الجانبية لخزعة لهنه

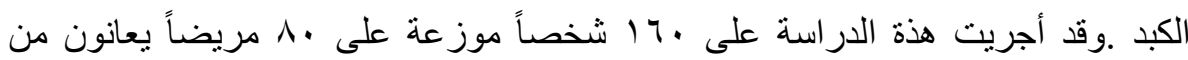

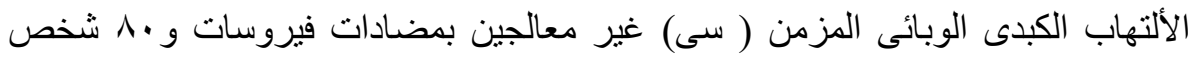
كمجو عة ضابطة .

وقد أجرى الأتى : أخذ التاريخ و الفحص العام وأختبارات وظائف الكبد و أستخر اج الحمض النووى من الدم الكامل للكثف عن مستوى MiR 129-5-p وتم عمل أشعة سونار و أخذ وخزعة من الكبد لتحديد درجة التليف وتم تقسيم المرضى الى أربع مجموعات على حسب درجة تليف الكبد . يظهر التحليل الأحصائى أن هنالك فروق ذات دلالة أحصائية بين مرضى الألتهاب الكبدى

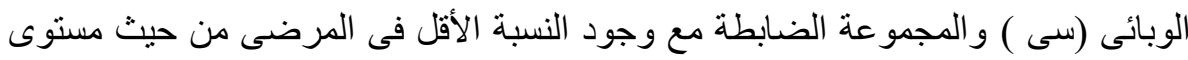
. MiR 129-5-p

أوضحت نتائجنا أن مستوى MiR 129-5-p قد تم تقلبلة فى درجة التلبف الثديدة ( قد تم

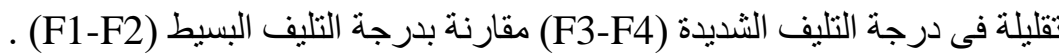
أظهر تحليل الأداء التشخيصى القيمة التشخيصية ل MiR 129-5-p للتمييز بين التليف الثديد (F4,F3) عن الأخرين (F2,F1) وقد وجدت درجة الحساسية • •\% ودرجة الخصوصية •9\% عند نقطة 0.035 بناءً على هذة النتائج فأن قياس مستوى MiR 129-5-p قد يكون علامة بيولوجية تتخيصية محتملة لتحديد درجة تليف الكبد . 